\title{
Preliminary Study
}

\section{Survey of Atheromatous Peripheral Artery Disease Cases in Selected Hospitals}

\author{
JOHN B. JOHNSON, M.D., GUAROCUYA BATISTA, M.D., FRANCIS BLACKWELL, M.D., and \\ LOUIS C. BROWN, M.D.
}

\begin{abstract}
$A^{\mathrm{T}}$ THEROSCLEROTIC occlusive arterial disease of the legs is widely recognized as a difficult clinical problem in medical practice. Chronicity, long-term hospitalization, and a high incidence of amputation are characteristic in patients with this disorder. The suspicion exists that this clinical entity not infrequently heralds serious coronary or cerebrovascular disease. That diabetes mellitus in some way is an accelerating and, at times, an ominous factor in this disease is increasingly clear. Renewed interest in atherosclerotic peripheral arterial insufficiency has been aroused as a result of the successful use of vascular grafts in patients with segmental occlusive arterial disease.

We have been unable to find reports of largescale investigations designed to delineate the magnitude and characteristics of atherosclerotic peripheral arterial insufficiency in the adult population of the United States, either as a public health problem or as a socioeconomic problem for the family and community. In recent years, a number of community and census
\end{abstract}

All of the authors are with the cardiovascular laboratory, department of medicine of Howard University and Freedmen's Hospital, Washington, D.C. Dr. Johnson is professor of medicine and director of the laboratory, and Dr. Batista, Dr. Blackwell, and Dr. Brown are fellows in cardiovascular diseases. Dr. Johnson is also a consultant in medicine, Mt. Alto Veterans Administration Hospital, Washington, D.C.

The study was supported in part by a grant from the National Heart Institute, Public Health Service. tract health surveys dealing with cardiovascular diseases have been reported, but these studies have not provided pertinent information on the prevalence of this disorder in the population $(1,2)$.

During the past 5 years our laboratory has evaluated a large number of medical and surgical patients with atherosclerotic peripheral arterial disease using arteriography and other diagnostic methods. We have been impressed with the complexity and magnitude of this condition in our hospital. Because of this experience, we made a limited survey of the extent of atherosclerotic peripheral arterial insufficiency, hereafter designated PAI, in several other hospitals. The records of seven hospitals, including our own, in five different States were searched in the study; three of these were veterans hospitals. The hospitals selected include small and large civilian and veterans hospitals in three regions of the country. In one veterans and one civilian hospital, the staff had special interest in peripheral arterial disease.

This study was designed to provide information on the frequency of this disorder as a cause for hospitalization of adults, the relative number of hospital days per discharge, and on the frequency of amputations of the feet and legs during the course of the disease. In addition, information was sought on the prevalence and significance of diabetes mellitus in PAI patients. Because of the limited number and nonrandom selection of hospitals surveyed, the study is preliminary in nature, but we believe significant enough, nevertheless, to serve as a 
basis and stimulus for a comprehensive largescale study of this disorder as a public health problem.

\section{Materials and Methods}

All PAI patients under age 40 were excluded from the study. Those included are discharged patients for whom atherosclerotic peripheral arterial insufficiency was the major cause of hospitalization. The diagnosis of PAI was accepted only if the record revealed good clinical evidence such as intermittent claudication, chronic ulceration, or gangrene, each associated with objective evidence of impaired arterial circulation in the legs as found by study of the pulses, oscillometric indices, or arteriography. In patients with recent leg amputation, the pathological report of the specimen was also used as evidence. For the purpose of this study, an amputee is defined as a patient with amputation (for PAI) of the extremity at or above the ankle.

The geographic location and type of hospital and number of adult general medical and surgical discharges and PAI (above age 40 years) discharges in the study are presented in table 1. The three largest hospitals, Hines VA, Mt. Alto VA, and Jewish Hospital-separately and together-serve a broad ethnic spectrum of the population whereas the other four hospitals draw patients predominantly from the Negro segment of their communities.
Table 2. Average hospital days for PAl patients compared with general medical and surgical patients in seven selected hospitals, United States, 1954-59

\begin{tabular}{|c|c|c|}
\hline \multirow{2}{*}{ Hospitals } & \multicolumn{2}{|c|}{$\begin{array}{l}\text { Hospital days per } \\
\text { discharge }\end{array}$} \\
\hline & $\begin{array}{l}\text { General } \\
\text { medical } \\
\text { and } \\
\text { surgical }\end{array}$ & PAI \\
\hline $\begin{array}{l}\text { Civilian: }{ }^{1} \\
\text { Freedmen's. } \\
\text { Jewish. } \\
\text { J. A. Andrew } \\
\text { Florida A. \& } \bar{M}^{-}\end{array}$ & $\begin{array}{r}\text { 15. } 8 \\
11.2 \\
11.2 \\
\text { 7. } 7\end{array}$ & $\begin{array}{l}57.7 \\
20.1 \\
\text { 46. } 9 \\
24.8\end{array}$ \\
\hline $\begin{array}{l}\text { Veterans Administration: } \\
\text { Mt. Alto } \\
\text { Hines } \\
\text { Tuskegee. }\end{array}$ & $\begin{array}{l}21.5 \\
32.5 \\
42.8\end{array}$ & $\begin{array}{l}61.7 \\
96.5 \\
75.2\end{array}$ \\
\hline
\end{tabular}

1 Average length of stay for patients age 45 years and older in short-stay hospitals, U.S., 1958-60, is 12.2 days.

The period of study was 1 year at Jewish Hospital, St. Louis, 4 years at Florida Agricultural and Mechanical University Hospital, and 5 years at each of the other five hospitals.

\section{Resulis of Survey}

More than 100,000 adult hospital discharges were examined. A total of 387 PAI patients, with 489 discharges, were found in these hospital populations. They represent a far

\section{Table 1. Prevalence of peripheral arterial insufficiency among medical and surgical discharges of}

adults in selected hospitals, United States, 1954-59

\begin{tabular}{|c|c|c|c|c|c|c|}
\hline \multirow{2}{*}{ Hospitals } & \multirow{2}{*}{$\begin{array}{l}\text { Survey } \\
\text { period }\end{array}$} & \multicolumn{2}{|c|}{$\begin{array}{l}\text { General medical and } \\
\text { surgical discharges }\end{array}$} & \multicolumn{3}{|c|}{$\begin{array}{l}\text { Discharges of patients with } \\
\text { peripheral arterial insufficiency }\end{array}$} \\
\hline & & $\begin{array}{c}1956 \\
(1 \text { year })\end{array}$ & $\begin{array}{l}\text { Total } \\
\text { period }\end{array}$ & Number & $\begin{array}{c}\text { Per 1,000 } \\
\text { hospital } \\
\text { discharges }\end{array}$ & Patients \\
\hline $\begin{array}{l}\text { Civilian: } \\
\text { Freedmen's, Washington, D.C. } \\
\text { Jewish Hospital, St. Louis, Mo , } \\
\text { J. A. Andrew, Tuskegee, Ala } \\
\text { Florida A. \& M., Tallahassee, Fla.... }\end{array}$ & $\begin{array}{l}1954-58 \\
1956 \\
1954-58 \\
1955-58\end{array}$ & $\begin{array}{r}2,779 \\
5,448 \\
830 \\
858\end{array}$ & $\begin{array}{r}12,477 \\
5,448 \\
3,904 \\
3,536\end{array}$ & $\begin{array}{l}57 \\
42 \\
27 \\
17\end{array}$ & $\begin{array}{l}\text { 4. } 6 \\
\text { 7. } 7 \\
6.9 \\
4.8\end{array}$ & $\begin{array}{l}54 \\
33 \\
23 \\
15\end{array}$ \\
\hline $\begin{array}{l}\text { Veterans Administration: } \\
\text { Mt. Alto, Washington, D.C. } \\
\text { Hines, Hines, Ill } \\
\text { Tuskegee, Tuskegee, Ala. }\end{array}$ & $\begin{array}{l}1954-58 \\
1955-59 \\
1954-58\end{array}$ & $\begin{array}{r}3,856 \\
10,429 \\
2,522\end{array}$ & $\begin{array}{l}18,561 \\
52,700 \\
13,003\end{array}$ & $\begin{array}{r}140 \\
184 \\
22\end{array}$ & $\begin{array}{l}7.5 \\
3.5 \\
1.7\end{array}$ & $\begin{array}{r}84 \\
156 \\
22\end{array}$ \\
\hline
\end{tabular}


Table 3. Prevalence of clinical diabetes mellitus in patients with peripheral arterial insufficiency in seven selected hospitals, United States, 1954-59

\begin{tabular}{|c|c|c|c|c|}
\hline \multirow{3}{*}{ Hospitals } & \multicolumn{4}{|c|}{$\begin{array}{c}\text { Patients with peripheral arterial } \\
\text { insufficiency }\end{array}$} \\
\hline & \multirow{2}{*}{$\begin{array}{l}\text { Nondia- } \\
\text { betics }\end{array}$} & \multicolumn{2}{|c|}{ Diabetics } & \multirow{2}{*}{ Total } \\
\hline & & Number & Percent & \\
\hline Civilian & 54 & 71 & 56.8 & 125 \\
\hline Freedmen's & 26 & 28 & 51.9 & 54 \\
\hline Jewish & 10 & 23 & 69.7 & 33 \\
\hline J. A. Andrew & 12 & 11 & 47.8 & 23 \\
\hline Florida A. \& M & 6 & 9 & 60.0 & 15 \\
\hline Veterans Adminis- & & & & \\
\hline $\begin{array}{l}\text { tration } \\
\text { Mt. Alto. }\end{array}$ & $\begin{array}{r}171 \\
55\end{array}$ & $\begin{array}{l}91 \\
29\end{array}$ & $\begin{array}{l}34.7 \\
34.5\end{array}$ & $\begin{array}{r}262 \\
84\end{array}$ \\
\hline Hines & 105 & 51 & 32.7 & 156 \\
\hline Tuskegee _ & 11 & 11 & 50.0 & 22 \\
\hline
\end{tabular}

greater socioeconomic and morbidity problem for the communty than is apparent from their absolute numbers.

Comparative data on PAI and general medical and surgical hospital discharges with reference to hospital morbidity and bed occupancy are presented in table 2. These data reveal that in the general hospitals, where beds are usually at a premium, PAI patients require approximately two to four times as many hospital days per discharge as do general medical and surgical patients. The age distribution showed that approximately 55 percent of the $\mathrm{PAI}$ patients were in the age group 50-79 years. Diabetes mellitus and PAI. Table 3 shows the prevalence of clinically overt diabetes mellitus among the PAI population. In the civilian hospitals, 48 to 70 percent of the PAI patients were known diabetics. In the veterans hospitals, the percentage of known diabetics was much lower, perhaps because of the absence of female patients. In former years the dreaded complication for the diabetic was diabetic acidosis. Now, with the efficient use of insulin, effective dietary management, and more recently, the use of oral hypoglycemic agents, the dreaded complication for the middle-aged and elderly diabetic is peripheral arterial insufficiency with the attendant possibility of extremity amputation.

Amputees in the PAI population. The prevalence of PAI-related amputees in the peripheral arterial insufficiency group is given in table 4. The frequency of amputations among hospitalized PAI patients apparently varies to some degree depending on the medical community's orientation to early diagnosis, skilled prophylaxis, arteriographic localization, and graft replacement for segmental disease. The

Table 4. Prevalence of amputees among patients with atherosclerotic peripheral arterial insufficiency in seven selected hospitals, United States, 1954-59

\begin{tabular}{|c|c|c|c|c|c|c|c|}
\hline \multirow{4}{*}{ Hospitals } & \multicolumn{6}{|c|}{ Patients with peripheral arterial insufficiency } & \multirow{4}{*}{$\begin{array}{l}\text { Percent } \\
\text { amputees } \\
\text { of PAI } \\
\text { patients }\end{array}$} \\
\hline & \multicolumn{3}{|c|}{ Diabetic patients } & \multicolumn{3}{|c|}{ Nondiabetic patients } & \\
\hline & \multirow{2}{*}{ Total } & \multicolumn{2}{|c|}{ Amputees 1} & \multirow{2}{*}{ Total } & \multicolumn{2}{|c|}{ Amputees 1} & \\
\hline & & Number & Percent & & Number & Percent & \\
\hline $\begin{array}{l}\text { Civilian } \\
\text { Freedmen's } \\
\text { Jewish } \\
\text { J. A. Andrew } \\
\text { Florida A. \& M.- }\end{array}$ & $\begin{array}{r}71 \\
28 \\
23 \\
11 \\
9\end{array}$ & $\begin{array}{r}51 \\
22 \\
11 \\
9 \\
9\end{array}$ & $\begin{array}{r}71.8 \\
78.6 \\
47.8 \\
81.8 \\
100.0\end{array}$ & $\begin{array}{r}54 \\
26 \\
10 \\
12 \\
6\end{array}$ & $\begin{array}{r}30 \\
14 \\
0 \\
10 \\
6\end{array}$ & $\begin{array}{r}55.6 \\
53.8 \\
83.3 \\
100.0\end{array}$ & $\begin{array}{r}64.8 \\
6.7 \\
33.3 \\
82.6 \\
100.0\end{array}$ \\
\hline $\begin{array}{l}\text { Veterans Administration } \\
\text { Mt. Alto . } \\
\text { Hines } \\
\text { Tuskegee }\end{array}$ & $\begin{array}{l}91 \\
29 \\
51 \\
11\end{array}$ & $\begin{array}{l}51 \\
26 \\
15 \\
10\end{array}$ & $\begin{array}{l}56.0 \\
89.7 \\
29.4 \\
90.9\end{array}$ & $\begin{array}{r}171 \\
55 \\
105 \\
11\end{array}$ & $\begin{array}{r}75 \\
38 \\
29 \\
8\end{array}$ & $\begin{array}{l}43.9 \\
69.1 \\
27.6 \\
72.7\end{array}$ & $\begin{array}{l}48.1 \\
76.2 \\
28.2 \\
81.8\end{array}$ \\
\hline
\end{tabular}

${ }^{1}$ Includes only amputation at or above level of ankle. All amputations were disease related. 
Table 5. Estimated prevalence of advanced PAI among hospital discharges, United States, 1954-59

\begin{tabular}{l|r|r|r|r}
\hline $\begin{array}{c}\text { Hospital } \\
\text { discharges }\end{array}$ & $\begin{array}{c}\text { Annual average in } \\
\text { seven hospitals } \\
\text { surveyed }\end{array}$ & $\begin{array}{r}\text { Annual average in } \\
\text { U.S. short-term } \\
\text { general hospitals } \\
1958-59\end{array}$ \\
\cline { 2 - 4 } & $\begin{array}{c}\text { Civilian } \\
\text { hospitals }\end{array}$ & $\begin{array}{c}\text { Veterans } \\
\text { hospitals }\end{array}$ & $\begin{array}{c}\text { Civilian } \\
\text { hospitals }\end{array}$ & $\begin{array}{c}\text { Veterans } \\
\text { hospitals }\end{array}$ \\
\hline $\begin{array}{c}\text { Adult general } \\
\text { medical and } \\
\text { surgical_-- }\end{array}$ & 9,915 & 16,837 & $6,279,000$ & 277,000 \\
$\begin{array}{c}\text { PAI per 1,000 } \\
\text { general medi- } \\
\text { cal and sur- } \\
\text { gical }\end{array}$ & 6.35 & 4.11 & 6.35 & 4.11 \\
$\begin{array}{c}\text { Peripheral } \\
\text { arterial in- } \\
\text { sufficiency -- }\end{array}$ & 63.0 & 69.2 & 140,000 & 11,000 \\
\hline
\end{tabular}

1 Estimate based on U.S. National Health Survey statistics (reference 3) and our survey data.

percentage of amputees among PAI patients was considerable in all hospitals among diabetics and nondiabetics, but more so among the diabetics. Of the $207 \mathrm{PAI}$ amputees in the study, 20 percent were double amputees.

\section{Estimate of National Magnitude}

The magnitude of atherosclerotic occlusive arterial disease of the legs as a public health problem will be difficult to determine. In itself, it is not a common cause of death, and therefore its magnitude will not be reflected in vital statistics reports. Hospital studies of the type reported here will provide prevalence data only of the late or complicated states of PAI since many patients with indolent ischemic ulcers or with ischemic muscles and nerves, as in patients with intermittent claudication and paresthesia but otherwise uncomplicated, are not admitted to general hospitals in large numbers. The continuing shortage of hospital beds for acute illness and the little, until recently, that could be offered these patients therapeutically other than amputation are responsible for the small number of these hospital patients.

The average amnual PAI discharges of our survey, 132.2, represent 5.03 PAI discharges per 1,000 adult general medical and surgical hospital discharges (table 5). In an effort to obtain a gross estimate of the national magnitude of atherosclerotic peripheral arterial insufficiency, we have utilized these data in conjunction with the average annual adult hospital discharges in the United States reported in health statistics from the United States National Health Survey (3).

The National Health Survey statistics are limited to adult discharges from short-stay hospitals, both civilian and veteran (excluding maternity cases). In these respects, they are comparable to the general hospital discharge data in our survey. Their data differ from our data, however, in that our adult hospital discharges represent ages 18 years and older, while the age span we selected from the National Health Survey data includes only those patients 45 years and older. If we apply the PAI rates of 6.35 for civilian hospitals and 4.11 for veterans hospitals per 1,000 general medical and general surgical discharges to the National Health Survey data, atherosclerotic peripheral arterial insufficiency discharges from hospitals in the United States would be estimated in excess of 40,000 annually.

Had we been able to limit our general hospital discharge data to adults age 45 years and above, as in the National Health Survey data, our discharge rates would have been well above 6.35 and 4.11 PAI per 1,000 general medical and general surgical discharges. In view of these considerations, it is apparent that our calculation of 40,000 PAI hospital discharges annually, as a gross estimate of the magnitude of atherosclerotic peripheral arterial insufficiency as a national public health problem is, undoubtedly, a conservative estimate.

Myocardial infarction or cerebrovascular accidents. In the hospital charts of PAI patients, the frequency of documented episodes of acute myocardial infarction or cerebrovascular accidents was notable. Data on these episodes were tabulated for three hospitals, comprising 273 PAI patients. On the same or subsequent hospital admission of the study period, 14 percent had acute myocardial infarction and 7 percent had cerebrovascular accidents.

\section{Discussion}

This preliminary study of the public health significance of atheroscelerotic peripheral ar- 
terial insufficiency seems clearly to indicate that the prevalence of this condition in the United States is of major proportions. Our estimate of 40,000 PAI hospital discharges annually from short-term general hospitals not only is a conservative estimate of prevalence of advanced stages of this disorder, but the limitation of our data to hospital discharges precludes any assessment of prevalence of cases in the less advanced stages which do not yet require hospitalization.

The condition is chronic, requiring multiple hospitalizations with two to four times as many days per hospital stay as for general medical and general surgical patients. The disabling nature of this disorder, including surgical amputation, brings loss of employment (frequently for the breadwinner of the family).

Atherosclerotic peripheral arterial insufficiency is not uncommonly associated with diabetes mellitus, in which event its course seems rapidly accelerated $(4,5)$. One investigator has shown that in ambulatory PAI patients without previous diabetic history, 20 percent had unsuspected diabetes mellitus, and only 23 percent had normal glucose tolerance curves (6).

Available evidence suggests that atherosclerotic peripheral arterial insufficiency, in addition to its disabling effects on the legs, may actually presage the development of acute coronary thrombosis or cerebrovascular accidents.

In addition to our data, other investigators recently reported a followup study of a large group of patients with atherosclerotic obliterative disease of the femoral artery. This study showed that 36 percent of the nondiabetic and 62 percent of the diabetic PAI patients were dead in 8 years. Eighty-two percent of these deaths were due to some form of cardiovascular disease, and 64 percent of these were caused by myocardial infarction, congestive heart failure, or were sudden deaths $(\boldsymbol{y})$.

\section{Summary}

A survey of 100,000 adult discharges from 7 short-term general and veterans hospitals was conducted to determine the size of the problem of advanced peripheral arterial insufficiency. The 387 PAI patients in this population had
489 hospital discharges, each of which required 2 to 4 times as many hospital days per discharge as did general medical and general surgical patients. Clinical diabetes mellitus was found in 57 percent of the civilian PAI patients and 35 percent of the veteran PAI patients. The rate of amputation of extremities was higher in diabetics of both groups.

The survey data were used with the statistical data of the National Health Survey on adult hospital discharges from short-stay general hospitals to estimate the prevalence of advanced PAI on a national scale. The prevalence of advanced PAI was calculated in excess of 40,000 hospital discharges annually.

Peripheral arterial insufficiency appears to be an important public health problem in terms of the number of persons afflicted, prolonged morbidity, loss of legs, and expensive prolonged hospitalization. Of more serious significance, however, is the fact that symptomatic atherosclerotic PAI appears to reflect the presence of profound atherosclerotic disease of the coronary and cerebral vessels, presaging serious coronary or cerebral vascular complications.

\section{REFERENCES}

(1) Origin and program of United States National Health Survey. Health Statistics, U.S. National Health Survey. PHS Publication No. 584-A1, U.S. Government Printing Office, Washington, D.C., May 1958.

(2) Epidemiologic approaches to heart disease: The Framingham study. Amer J Public Health 41 : 279 (1951).

(3) Hospital discharges and length of stay: shortstay hospital. Health Statistics, U.S. National Health Survey. PHS Publication No. 584-B32, U.S. Government Printing Office, Washington, D.C., April 1962.

(4) Ricketts, H. T. : The problem of degenerative vascular disease in diabetes. Amer $J$ Med 19: 933-945 (1955).

(5) Kramer, D. W., and Perilstein, P. K. : Peripheral vascular complication in diabetes mellitus: a survey of 3,600 cases. Diabetes 8 : 384-387, September-October 1958.

(6) Bartels, C. C., and Fiore, R. R.: Unsuspected diabetes mellitus in peripheral vascular disease. New Eng J Med 259: 633-635 (1958).

(7) Schadt, D. C., Hines, E. A., Juergens, J. L., and Barker, N. W.: Chronic atherosclerotic occlusion of the femoral artery. JAMA 175: 89-92, March 1961. 